Research Report No. 42/2010

\title{
Israel's Seizure of the Gaza-Bound Flotilla: Applicable Laws and Legality
}

Craig Scott

Osgoode Hall Law School of York University

Follow this and additional works at: http://digitalcommons.osgoode.yorku.ca/clpe

\section{Recommended Citation}

Scott, Craig, "Israel's Seizure of the Gaza-Bound Flotilla: Applicable Laws and Legality" (2010). Comparative Research in Law \&" Political Economy. Research Paper No. 42/2010.

http://digitalcommons.osgoode.yorku.ca/clpe/109 


\section{OSGOODE}

OSCOODE HALL LAW SCHOOL

YOR K UNIVERSITY

\section{OSGOODE HALL LAW SCHOOL}

Comparative Research in Law \& Political Economy

RESEARCH PAPER SERIES

Research Paper No. 42/2010

Israel's seizure of the Gaza-bound flotilla: applicable laws and legality

Craig M. Scott

\section{Editors:}

Peer Zumbansen (Osgoode Hall Law School, Toronto, Director, Comparative Research in Law and Political Economy)

John W. Cioffi (University of California at Riverside)

Lisa Philipps (Osgoode Hall Law School, Associate Dean Research)

Nassim Nasser (Osgoode Hall Law School, Toronto,

Production Editor)

Comparative Research in Law \& Political Economy 


\title{
Israel's seizure of the Gaza-bound flotilla: applicable laws and legality*
}

\author{
by Craig Scott ${ }^{1}$
}

\begin{abstract}
:
The present working paper analyzes the applicable laws and legality of Israel's naval blockade on Gaza and of the enforcement of that blockade through the seizure of a number of vessels, notably the Mavi Marmara, on May 31, 2010. It includes a comparison between that analysis and the analysis of the just-released (September 27, 2010) Report of the international factfinding mission to investigate violations of international law, including international humanitarian and human rights law, resulting from the Israeli attacks on the flotilla of ships carrying humanitarian assistance. This three-member mission was chaired by Judge Karl T. Hudson-Phillips, Q.C., retired Judge of the International Criminal Court and former Attorney General of Trinidad and Tobago. Its mission was established by the UN Human Rights Council in resolution 14/1 of 2 June 2010. Suggestions are made about questions of law to which two remaining panels or commissions of inquiry may wish to give special attention. One such question is whether or not a belligerent right of visit of vessels for purposes of arms interdiction requires a naval blockade first to be in place. A second question meriting further attention is how to think about the interaction of personal rights of self-defence of both the passengers aboard the ships and the soldiers ordered to seize the ships, in terms of the analysis of the necessity and proportionality of specific actions taken by Israeli soldiers. A third question is whether, without addressing the matter in any detail, the Hudson-Phillips report unhelpfully blurred the jus in bello right of visit within the laws of war and the jus ad bellum right of states to self-defence. The first of these two other commissions is the four-member Panel of Inquiry established by UN Secretary-General Ban Ki-moon, with the support of the UN Security Council; that panel is chaired by the former Prime Minister of New Zealand, Geoffrey Palmer, and vicechaired by the former President of Colombia, Alvaro Uribe, and also includes panel members from Israel and Turkey. The second is Israel's own "Public Commission to Examine the Maritime Incident of 31 May 2010" chaired by retired Israeli Supreme Court justice, Judge Jacob Terkul, and including as non-voting observers Northern Ireland's former First Minister, Lord William David Trimble, and a former Judge Advocate General for Canada, Brigadier General (retired) Ken Watkin.
\end{abstract}

\footnotetext{
${ }^{*}$ As originally published on June 4 \& 10, 2010, and supplemented on October 16, 2010.

${ }^{1}$ Professor of Law, Osgoode Hall Law School of York University, Toronto; Director, Nathanson Centre on Transnational Human Rights, Crimes and Security.
} 


\section{INTRODUCTION}

The present working paper, from section 2 onward, includes a verbatim reproduction of a June 4, 2010, online analysis of the legality of Israel's May 31, 2010 seizure of the Gaza-bound flotilla that led to nine deaths and a significant number of injuries to passengers aboard one of the ships in the flotilla, the Mavi Marmara, as well as injuries to some Israeli soldiers who boarded the Mavi Marmara. ${ }^{2}$ The paper also includes a Postscript reproducing a June 10, 2010, reply to a comment on the June 4 article. The present Introduction (section 1) is new. Occasionally, in sections 2 and 3 as well as the Postscript, a clarifying footnote is added; as there were no footnotes in the original piece, any footnote in those sections is by definition new.

The paper was originally published as an editorial in the online blog called The Court, run by Osgoode Hall Law School. ${ }^{3}$ The editorial was initially generated by a request from the Canadian Broadcasting Corporation ( $\mathrm{CBC}$ ) for replies to two questions put to myself and to my colleague at Toronto's other law school at the University of Toronto, Professor Ed Morgan. My reply to the two questions were then used as source material for CBC.ca's online coverage of the impending encounter between the Rachel Corrie - a ship that had missed being in the original

\footnotetext{
${ }^{2}$ At the time of writing, only three days after the first reports of the incident, it was not clear that injuries (although no deaths) also occurred during the seizure of some of the other ships in the flotilla. Nor was it known at the time what treatment occurred after the ships had been secured. Considerable clarity appears to have emerged with the report of a fact-finding mission created by the UN Human Rights Council, which reported on September 27, 2010. See Report of the international fact-finding mission to investigate violations of international law, including international humanitarian and human rights law, resulting from the Israeli attacks on the flotilla of ships carrying humanitarian assistance, UN Doc A/HRC/15/21, 27 September 2010, available in PDF for download at http://www2.ohchr.org/english/bodies/hrcouncil/docs/15session/A.HRC.15.21 en.pdf (last accessed October 16, 2010) [henceforth the Hudson-Phillips Report]. The mission was established by the UN Human Rights Council in resolution 14/1 of 2 June 2010. The mission was chaired and headed by Judge Karl T. Hudson-Phillips, Q.C., retired Judge of the International Criminal Court and former Attorney General of Trinidad and Tobago. The two other appointed members were Sir Desmond de Silva, Q.C. of the United Kingdom, former Chief Prosecutor of the United Nations-backed Special Court for Sierra Leone and Ms. Mary Shanthi Dairiam of Malaysia, founding member of the Board of Directors of the International Women's Rights Action Watch Asia Pacific and former member of the Committee on the Elimination of Discrimination against Women.
}

${ }^{3}$ See Craig Scott, "Israel's seizure of the Gaza-bound flotilla: applicable law and legality", TheCourt.ca, June 4, 2010, at http://www.thecourt.ca/2010/06/04/seizure-of-the-gaza-flotilla/ (last accessed October 16, 2010). 
flotilla due to engine trouble - and Israeli armed forces. ${ }^{4}$ CBC.ca also linked to my full replies as they appeared in TheCourt.ca on the same day. ${ }^{5}$

This paper is being made available, in the form of a working paper in a new venue (SSRN.com), in the context of the recent release on September 27, 2010, of the Hudson-Phillips Report and in the context of two other inquiries or investigations that have yet to issue final reports. ${ }^{6}$ One is a four-member panel established by Secretary-General Ban Ki-moon separately and independently from the Human Rights Council Hudson-Phillips mission. ${ }^{7}$ This "Panel of Inquiry on the flotilla incident of 31 May 2010" was constituted when its last two members, one from Israel and one from Turkey, were appointed by Secretary-General Ban on August 9, $2010 .^{8}$ The

${ }^{4}$ See CBC news, "FAQs on the ships trying to reach Gaza," June 4, 2010, at http://www.cbc.ca/world/story/2010/06/04/f-gaza-ships.html (last accessed October 16, 2010).

${ }^{5}$ Ibid. See the link back to TheCourt.ca, note 3, at the upper right of the web page. Also linked in the same box is Professor Morgan's opinion editorial of the day before in the Globe and Mail: Ed Morgan, "Israel's naval blockade pitches and rolls with the Law of the Sea", The Globe and Mail, June 3, 2010, at http://www.theglobeandmail.com/news/opinions/israels-naval-blockade-pitches-and-rolls-with-thelaw-of-the-sea/article1589981/ (last accessed October 16, 2010).

${ }^{6}$ Hudson-Phillips report, at note 2.

${ }^{7}$ Secretary-General Ban created the panel, after he publicly stated the need for it and then after the Security Council endorsed the Secretary-General's statement in its own Presidential Statement (not in a Resolution). See Statement by the President of the Security Council, UN Doc S/PRST/2010/9, 1 June 2010, at http://daccess-dds-ny.un.org/doc/UNDOC/GEN/N10/382/79/PDF/N1038279.pdf?OpenElement (last accessed October 16, 2010). The quasi-operative paragraph is the third, which reads: "The Security Council takes note of the statement of the UN Secretary-General on the need to have a full investigation into the matter and it calls for a prompt, impartial, credible and transparent investigation conforming to international standards." I use the term "quasi-operative" because the formal authority for creating and naming the panel remained with Ban within his powers as Secretary-General, a power he also used to establish a three-member panel to advise him on matters related to alleged war crimes in the final stages of the war in Sri Lanka (without any additional endorsement or "call for" that panel from the Security Council). The Presidential Statement also contained some other paragraphs with possible normative significance, including the fourth paragraph reading: "The Security Council stresses that the situation in Gaza is not sustainable. The Council re-emphasizes the importance of the full implementation of Resolutions 1850 and 1860. In that context, it reiterates its grave concern at the humanitarian situation in Gaza and stresses the need for sustained and regular flow of goods and people to Gaza as well as unimpeded provision and distribution of humanitarian assistance throughout Gaza." Both this Statement of the President and Security Council resolutions 1860 were referred to in the original June 4/10, 2010, version of this paper (now below in section 2 of the present paper).

8 "Secretary-General Announces Israeli, Turkish Members of Panel of Inquiry on 31 May Flotilla Incident," UN Doc SG/SM/13050 (9 August 2010), available at http://www.un.org/News/Press/docs/2010/sgsm13050.doc.htm (last accessed October 16, 2010) [The Palmer Panel]. The Panel of Inquiry consists of the former Prime Minister of New Zealand, Geoffrey Palmer, who is Chair of the Panel, the former (then outgoing) President of Colombia, Alvaro Uribe, who 
other inquiry is Israel's own "Public Commission to Examine the Maritime Incident of 31 May 2010" chaired by retired Israeli Supreme Court justice, Judge Jacob Terkul. ${ }^{9}$

Despite being written as an informal piece, sections 2 and 3 of the present working paper were argued as carefully as the limited time (less than a day) to answer the CBC's questions would permit. The analysis appears to dovetail with the legal analysis of the Hudson-Phillips Report of the applicable law and with its assessment of compliance with that law, in relation to the legality of the naval blockade and of the decision to enforce the blockade against the flotilla. Arguably, my analysis goes somewhat further with respect to some of the procedural requirements of a naval blockade, partly as interpreted against the contemporary international law of human rights. To the extent this is so, the remaining two inquiries - the Palmer Panel and the Turkel Commission - may wish to assess whether that analysis is sustainable.

That said, there may be another difference with respect to a free-standing right to stop ships reasonably suspected of carrying arms to the enemy, which I treat as dependent on the overall legality of the blockade - all the while accepting naval blockades can be lawful and, therefore, visitation of ships for arms-inspection purposes can also be lawful. While noting that it is controversial whether a lawful blockade is a threshold requirement for a right of visit, the Hudson-Phillips mission opts to recognize a separate right within the laws of war, which would include the right of a belligerent to search neutral vessels for arms under certain conditions. On the Hudson-Phillips reading of the law, as supported by the San Remo Manual, the right apparently does not depend on a more general blockade. My current assumption is that the Hudson-Phillips analysis is most probably correct in law, given the time and legal resources at the mission's disposal, and that the belligerent right of visit likely remains part of the customary international laws of war divorced from any need for there also to be a general blockade. However, my discussion (see the end of section 3 and also Postscript, below) of third-party monitoring of inspection visits, discussed in relation to arms but in the context of blockade law, may prove to be a safeguard that the other inquiries may wish to research in terms of whether it in fact is, first, a requirement within the law of blockade and, second, also a requirement

is Vice-Chair, Joseph Ciechanover (Israel's Panel member), and Özdem Sanberk (Turkey's Panel Member).

${ }^{9}$ See the website of the Public Commission to Examine the Maritime Incident of 31 May 2010 at http://www.turkel-committee.com/index-eng.html (last accessed October 16, 2010) [The Turkel Commission]. It members are retired Israeli Supreme Court Judge, Jacob Turkel (Chair), former President of Technion University and military expert, General (retired) Amos Horev, Professor of Civil Law at Tel Aviv University, Miguel Deutch, and former Israeli Foreign Ministry public servant, Ambassador Reuven Merchav. Originally, international law expert Shabtai Rosenne was a member of the commission, but passed away in September 2010. Two non-Israelis act as international observers with no voting power, Northern Ireland's former First Minister, Lord William David Trimble, and a former Judge Advocate General for Canada, Brigadier General (retired) Ken Watkin. 
within the law on belligerent right of visit. Of course, all of the preceding discussion is dependent on accepting, as I do and as does the Hudson-Phillips Report, that there is an armed conflict that triggers the application of the laws of war, whether the issue is the law of blockade or a separate body of law on the right of visit for arms detection and interdiction purposes. Although not discussed at any length by the Hudson-Phillips report, none of this analysis has anything to do with the prevailing law on the jus ad bellum right of self-defence, which on my view does not permit preventive interdiction of arms flows (again, to be clear, outside of an existing armed conflict) on the high seas unless the stringent tests for an actual or imminent attack (by an actor subject to the law on the use of force) are made out. The Hudson-Phillips report is somewhat ambiguous on this, arguably blurring the jus in bello right of visit discussion with a reference to the jus ad bellum right of self-defence.

The Hudson-Phillips report and my June 4/10, 2010, analysis appear to be ad idem on several general principles, such as the relationships between state responsibility and individual criminal responsibility as well as the significance for state responsibility of the root illegality of a blockade for the illegality of each and every enforcement measure.

Not surprisingly and appropriately to the task at hand, the Hudson-Phillips report spends most of its time on questions of the actual conduct of the seizure operations, as well as the subsequent treatment of the passengers and ships. On this, there was no basis on June 4/10, 2010, to make any assessments, beyond indicating the relevance of generally applicable principles of necessity and proportionality of law enforcement measures. That said, I did raise, in the final two paragraphs (see now the final two paragraphs of section 3, below) the issue of the significance of rights of personal self-defence on the part of the soldiers and of the passengers faced with what they understood to be both an illegal and an armed enforcement operation. It is not entirely clear, from my reading of the Hudson-Phillips report, how much this latter question factored into the analysis. On balance, however, it does appear that the overall Hudson-Phillips framework implicitly included an assessment of the reasonableness of exercises of personal self-defence - both by the passengers and by the soldiers - within the analysis of whether any given actions by Israeli soldiers were necessary and proportionate. The Palmer Panel and the Turkel Commission will undoubtedly benefit from the very careful and extensive findings of fact and analysis of the legal significance of those facts by the Hudson-Phillips report, which first tilling of the ground will hopefully permit these two inquiries to reflect further on the question of the interaction of two rights of personal (not, I emphasize again, state) self-defence.

\section{FIRST QUESTION POSED BY CBC: WHAT LAWS APPLY IN THE MILITARY SEIZURE OF A VESSEL IN INTERNATIONAL WATERS?}

At the most general, the applicable law is 'public international law' (PIL), which is the term for the law that primarily deals with interstate relations. Within PIL, the issue of military seizure of a vessel in international waters lies at the interface of two fields of PIL, the 'law of the sea' and the 'law of armed conflict.' In both areas, both treaties (e.g. the 1982 United Nations 
Convention on the Law of the Sea or the 1949 Geneva Conventions on the Laws of War) and unwritten 'customary international law' (or, custom) may be relevant to the rules that apply to a specific incident or dispute. Sometimes, a legal instrument will not in and of itself apply to all states, but will form the basis for states to consider custom has arisen; this is the case, for example, with respect to the classical law of naval blockades as set out in a document called the London Declaration of $1909 .^{10}$

Within the law relating to armed conflict, there is a standard distinction between how a state or other actors may conduct themselves once an armed conflict has started and the rules governing whether armed force can be used by a state that either initiates an armed conflict or responds to another actor's initiation of such a conflict. The former sub-field generally bears one of two labels, both meaning the same thing, namely, the 'laws of war' or 'international humanitarian law;' within that body of law, there is an even more specific body of law known as the law of naval blockade. The latter sub-field (on initiation of conflict or response to such initiation) is usually be referred to as the 'law on the use of force', within which there is also a more specific body of law known as the 'law of self-defence.' Latin terms inherited form previous eras of PIL speak also of the distinction between jus in bello (roughly, the law in war) as distinguished from jus ad bellum (the law of going to war). Israel's justifications appear to intermingle both the jus in bello law of naval blockades and the jus ad bellum law of selfdefence.

In contemporary PIL, two other bodies of law are relevant beyond the law of the sea and the law of armed conflict. One is the law of the United Nations Charter, specifically the rules of the Charter that permit the UN Security Council to make law that is binding on all states as long as the matter falls within the broad subject matter of international peace and security; as a general matter, UN Security Council law can either modify or override rules that would otherwise be applicable. The other area of law is what is known as international human rights law' (including a sub-set of principles around the right to self-determination), an ever-growing body of law that is now widely accepted as not only applying during armed conflicts (not only in peacetime) but as sometimes going beyond or sometimes interpretively influencing the 'international humanitarian law' (recall: the rules of conduct once an armed conflict is underway).

As well, apart from treaties and custom, PIL also recognizes a category called 'general principles of law', which arguably is relevant by helping provide content for requirements of proportionality and necessity within the law that deals with excessive use of force whether as jus in bello or jus ad bellum.

\footnotetext{
${ }^{10}$ The intention here was to mention the London Declaration as an example of an indirect source of customary international law on naval blockades but not to leave the impression it is the only such source let alone exhaustive of the relevant customary rules. In addition, the San Remo Manual, discussed in the Hudson-Phillips Report, should also have been noted.
} 
Finally, national law will also come into play in a variety of ways. For example, any jurisdiction Israel asserts over foreign ships on the high seas needs to be authorized by Israeli law itself. For another example, it is Turkish national law that conferred nationality on some or all of the ships in the flotilla, with this conferral then having implications for Turkey's rights as a state under PIL with respect to vessels flying its flag. ${ }^{11}$

\section{SECOND QUESTION POSED BY CBC: WAS THE MAY 31 SEIZURE LEGAL?}

As with many areas of law, especially public international law, there can be reasonable differences of views both on exactly what legal rules apply and, once that is determined, whether the facts reveal a violation of one or more rules. What follows is the author's assessment of what appears to the author to be the most sustainable view, based on a combination of independent legal analysis and the dominant understanding of the applicable law within the international legal community. The bottom-line is that the boarding and seizure do not appear to have been legal while more facts are needed in order to know whether specific acts of force by Israeli commandos were also illegal.

\section{The Law of the Sea}

Both treaty and customary international law preclude any state from boarding and arresting far less, attacking - a ship that has another state's nationality on the high seas (which are those international waters beyond 12 nautical miles from any state's coast). There are a very few limited exceptions, such as the right of any state to accost, board, arrest and take to port a pirate ship or a slave-trading ship. No exceptions are relevant here in the case of the Gazaflotilla seizure.

It may be noted that a few states, notably the US, have over the years tried to assert some undefined right to seize ships on the high seas in order to arrest suspected terrorists. Most states do not accept such an exception exists. In any case, even if such an exception exists, there is no plausible case that the persons on board the flotilla ships were, in law, terrorists.

Israel's action thus violated the law of the sea unless it can successfully plead an exception under the laws of armed conflict.

\footnotetext{
${ }^{11}$ This assumption proves to have been overstated. The Hudson-Phillips report clarifies that only one of the vessels, the Gazze I, was flying the Turkish flag. The others were registered in a variety of jurisdictions, including the Comoros Islands (Mavi Marmara), Kiribati (Defne), the USA (Challenger I and Challenger II), Eleftheri Mesogios or Sofia (Greece), Sfendoni or Boat 8000 (Togo). The Rachel Corrie, which made its own voyage later, is registered in Cambodia.
} 


\section{The Laws of War / International Humanitarian Law}

Most would accept that an international armed conflict continues between Israel and Gaza (and/or the Hamas authorities in Gaza), notwithstanding Israel no longer physically occupying the Gaza strip. More specifically, Israel claims to be enforcing a naval blockade which is a method of warfare that assumes an ongoing armed conflict.

Various treaty and, likely, customary rules do permit naval blockades by one belligerent (here, Israel) as a method to prevent neutral ships (here, Turkish) from supplying war-related material to another belligerent (here, Gaza/Hamas) and, at least according to traditional law on naval blockades, as a method of more general economic coercion. ${ }^{12}$ By the classical rules, the blockade must be publicly announced and the line past which a blockade will be enforced must be precise and clear; further, for various reasons, the classical rules also require the blockade actually be effective (i.e. not just pronounced but enforced); finally, it must be applied impartially, that is, to all neutrals' ships as opposed only to the ships of some states. However, even under traditional laws of war (untouched by contemporary international human rights law), a "principle of humanity" applies to naval blockades such that supplies intended as humanitarian aid for the populace cannot be prevented from reaching the other belligerent if one of two conditions are met: : if the blockade has (or comes to have) the purpose of starving the civilian population or denying it other objects essential for its survival; or if the damage to the civilian population is, or may be expected to be, excessive in relation to the concrete and direct military advantage anticipated from the blockade. International human rights law almost certainly deepens the principle of humanity, for example, by influencing how to interpret the notions of "objects essential for survival" or "damage to the civilian population" that is "excessive."

Assuming the existence of an international armed conflict here, Israel does have the presumptive power to establish a blockade that operates in conformity with the law. However, should it turn out that the blockade is, for one or more reasons, unlawful, then the general principle would be that there can be no right to enforce an unlawful blockade - at least as long as the unlawfulness is of the sort that would be termed fundamental or a manifest breach of the law.

Notwithstanding that the law allows a naval blockade, the dominant legal view would seem to be that the blockade as a whole had become illegal well before the Gaza flotilla incident - and may indeed have been illegal virtually from the outset, three years ago, depending on its intent.

\footnotetext{
12 "Various treaty and, likely, customary rules..." was carelessly written and should now be taken to read "Various customary rules likely...".
} 
This illegality stems from reasons related to both the principle of humanity within the laws of war and that principle's interaction with contemporary international human rights law such as with respect to the rights to food, shelter, health, and, more generally security of the person.

Justice Richard Goldstone and his colleagues on a commission of inquiry established by the UN Human Rights Council after the 2008-09 land conflict between Israel and Gaza take the view that both in intent and in effect the Israeli blockade - land and sea, combined - is actually operating as a form of collective punishment or reprisal against the population at large. This is due to a combination of factors, including: evidence as to intent of Israel decision makers, evidence that quantities of humanitarian supplies that Israel permits into Gaza are grossly inadequate to the imperative of humanitarian relief, and evidence that many materials that should be permitted to enter (e.g. concrete) are in fact barred.

Further, UN Security Council Resolution 1860 of January 8, 2009 (during Israel's incursion into Gaza in response to rocket fire from Gaza) contains provisions that come close to calling for the blockade to be lifted or at the very least implemented in a way that meets humanitarian obligations. In Resolution 1860, the Security Council (which, it must be noted, includes Israel's stalwart ally, the US) "[c]alls for the unimpeded provision and distribution throughout Gaza of humanitarian assistance, including of food, fuel and medical treatment", "[w]elcomes the initiatives aimed at creating and opening humanitarian corridors and other mechanisms for the sustained delivery of humanitarian aid", and "[c]alls on Member States to support international efforts to alleviate the humanitarian and economic situation in Gaza." The reader should bear in mind that the failure of the Council to specifically declare the blockade illegal or to call for it to be lifted has to be read against the need to achieve the assent of the US for any resolution to be adopted. A broader analysis of the opinion of member states of the UN could well reveal that the large majority do take the view, with Justice Goldstone, that the blockade is illegal.

It is also worth noting that, after the seizure, the Security Council agreed on June 1 on what is known as a Presidential Statement (a step below a formal resolution). ${ }^{13}$ The President stated on behalf of the entire Council that "it reiterates its grave concern at the humanitarian situation in Gaza and stresses the need for sustained and regular flow of goods and people to Gaza as well as unimpeded provision and distribution of humanitarian assistance throughout Gaza." It also called on Israel to permit all the ships' goods to proceed to Gaza, although it did not say that this must occur by way of allowing the ships themselves to. Again, the United States' views had to be taken into account in crafting this Security Council statement.

There is also a more technical but still fundamental reason why the blockade has been illegal in its operation, a reason that also shows why the specific exercise of the blockade in the specific case of the Gaza flotilla was illegal (even if one refuses to accept the view that the blockade is illegal by virtue of excessive harm to the populace). Where a blockade is lawful, a blockading state still has the right to require a neutral ship to allow itself to be inspected in order to make

\footnotetext{
${ }^{13}$ See Statement of the President of the Security Council, note 7.
} 
sure that the cargo is indeed humanitarian and does not also include, for example, armaments. But, significantly, traditional laws of war long ago evolved to the point of recognizing the obligation of the blockading state to inspect cargo under the supervision of a neutral party, such as the International Committee of the Red Cross, in order to make sure humanitarian supplies are not seized or diverted from their intended destination. ${ }^{14}$

Especially when overlain with evidence that Israel's categories of humanitarian relief supplies are narrower than warranted and also in light of allegations that Israel has at times failed to send on supplies by land that it has said it would send after inspection, the failure of Israel to create a system of third party supervision arguably vitiates the entire blockade scheme. The specific failure to involve third party inspectors in the case of the Gaza flotilla, combined with there being no transparency as to what supplies will or will not eventually make their way to Gaza (because the boats are not permitted to continue to port in Gaza and have been seized), means that the boarding and seizure in this case was also an illegal implementation of the law of blockade.

\section{The Law of Self-Defence}

Israel often does not distinguish whether it is employing the blockade as a method within the laws of war in the context of an ongoing conflict or whether it views the blockade and the right to board and seize ships as part of the law of self-defence in response to threats of force (with, on this view, there being no need to find an underlying armed conflict to be underway). There are legal complexities involved in the melding of these two areas of law, but the better view is that the matter needs to be looked at as a matter of the methods of warfare within an ongoing armed conflict and not as the right to use force outside of a prior armed conflict. In any case, there is almost no support amongst states or scholars outside the US or Israel for viewing facts such as these as being sufficient to generate a right of self-defence. Israel's action would fall into the extreme end of the spectrum of the kind of preventative use of force that international law does not accept. International law instead requires that any threat be both clear and imminent before force can be used to take anticipatory action.

\section{Degree of Force in Implementation of the Blockade}

Principles of necessity and proportionality are relevant to the actual conduct of the operation to interdict the Gaza flotilla, whether one applies these principles as rules within the laws of war dealing with taking military measures against civilian actors, as constraints within the law of self-defence, or as principles that both international human rights law and general principles of law bring to bear on the situation.

\footnotetext{
${ }^{14}$ See the discussion in Section 1 on my assumption that the belligerent right of visit was part of the law of blockade. This may be incorrect.
} 
On this point, more clarity as to the facts and reflection, as those facts clarify, are still needed. However, a framing question must surely be: does boarding civilian ships i(that have announced the intention of delivering humanitarian aid) in darkness, by use of helicopter-delivered commandos, and so far away from the Gaza coast (and, it seems, four times as far out to sea as the normal blockade line of 20 miles from Gaza) contravene principles of necessity and proportionality that permeate contemporary international law? If the answer to this question is negative, then the method of seizure also violates international law, whether or not the blockade as whole or the blockade in its general operation is legal.

A word of caution is required here. None of this denies that the individual Israeli soldiers had the right to defend themselves if, as appears from some video, they were met by what seems a vicious use of weapons, such as metal bars, shown by Israeli video. The soldiers' specific use of force may turn out to have been excessive, but no one has all the facts at hand to know this yet. However, we should not let the issue of the justification of the lethal force during shipboard operations obscure the prior question of whether Israel's decision makers lawfully placed its own soldiers in this situation in the first place.

Nor does any of this go to whether those on board may also have had a right to personal defence or defence of the ship, depending on their perceptions of their own physical danger and taking into account the background of believed illegality of the blockade. As with the lethal use of guns by Israeli soldiers, all the facts will need to be clarified to know whether the resistors themselves used excessive force (as, I must say again, Israeli video certainly suggests was the case, in at least some situations where we see a group clubbing one or more downed soldiers).

\section{POSTSCRIPT}

On June 10, 2010, the following anonymous comment was made on the original June 4 article (i.e. Sections 2 and 3, above):

As several ships have been intercepted in the past few years fully laden with weapons and explosives, Israel has an existential right to check them. More aid gets into Gaza from Israel in 24 hours than what was on all of these ships combined. The goal is to break the blockade. Hamas loves all this rhetoric because they can then re-arm.

If the Palestinians wanted to live in peace with Israelis, this would have been over long ago. When grade 3 Palestinian school textbooks do not name 'Israel' on the map of the region, but rather name the entire area 'Palestine', and Jews are labeled as evil, there can never be peace. Palestinian children are absorbing hatred 'with their mother's milk'. Through all the violence and mayhem, deliberations, peace talks, and summits, the Palestinian goal has never changed: the elimination of a Jewish state called Israel.

Two hours later on the same day, I responded with the following observations: 
I completely agree that the fact of arms shipments and their interdiction is entirely relevant to Israel's rights within an armed conflict to impose and operate a naval blockade. ${ }^{15}$ Many international lawyers would not consider there to be an armed conflict of the sort that triggers such a laws-of-war right, but I do. If you read my piece carefully, however, it is not the right to operate a naval blockade that concerns me but $\mathrm{m}[\mathrm{y}]$ judgment that the naval blockade exceeds the constraints imposed by, and purposes allowable under, contemporary international law, with that body of law's inclusion of a principle of humanity within the laws of war and embrace of the interpretive impact of international human rights law on the laws of war. There are reasons an eminent lawyer like Justice Goldstone would conclude that the blockade is operating as (and perhaps was intended as) a form of collective punishment or a form of disproportionate coercion of the populace (that may have been permissible when the laws of war were less 'humanized', but that run afoul of the kinds of humanitarian strictures within principles of contemporary international law). It is not the stopping of ships in order to prevent weapons getting to Hamas that I object to, but doing so within the context of a blockade that Israel has allowed to be or become illegal by virtue of such things as a) the rules on what quantity and what kind of goods are allowed in, b) the lack of neutral third-party supervision of when, how and whether Israel lets goods in, and c) the impounding of ships and deportation of crews versus letting them proceed to Gaza to deliver goods after inspection*. There are means to operate a lawful blockade and Israel may yet find ways to create such legality, perhaps in response to the global response to the incident that led to such injuries (on all sides) and deaths (on one side). Whether such a lawful blockade would be wise becomes another question, but we are not yet at that stage - and the illegality to date has probably made Israel's ability to do this lawfully (after seeing the legal light) very difficult as there are strong calls from within Israel and not just outside Israel to end the blockade for the simple reason it is, on balance, counterproductive for Israel's security. Whether this is true or not, I am not in a position to judge; my point is that a different kind of blockade would probably not have led to this crisis even if the same violent encounter had occurred.

* On point (c), I admittedly need to find out more about whether Israel only impounds and deports if a ship seeks to 'run' the blockade, or whether they do so for all ships that are waylaid on the way to Gaza whether or not they cooperate in the inspection. If it is only in the former case, while it would not be lawful to do this where ships are seeking to deliver goods in the face of an illegal blockade (if the illegality rises to the level of making the blockade unenforceable), it would at least be more proportionate.

\footnotetext{
${ }^{15}$ See, again, the discussion in Section 1 on my assumption that the belligerent right of visit was part of the law of
} blockade. This may be incorrect. 